\title{
A Challenge from Teaching to Social Movement: Bediüzzaman Said Nursi's Struggles for Modification in Turkey
}

Ramli Awang

Faculty of Islamic Civilization, University Technology Malaysia, Malaysia; ramly@utm.my

Kamaruzaman Yusoff

Faculty of Islamic Civilization, University Technology Malaysia, Malaysia; y.kamaruzaman@utm.my

Mansoureh Ebrahimi

Faculty of Islamic Civilization, University Technology Malaysia, Malaysia; mansoureh@utm.my

Omer Yilmaz

History Department, The National University of Malaysia, Malaysia; omeryilus@yahoo.com

\author{
Doi:10.5901/mjss.2015.v6n6s1p444
}

\section{Abstract}

Bediüzzaman Said Nursi played a major role in Turkish society in the field of promoting Islam. The struggle that he started in Turkey brought about some conflicts between him and the newly established government of Turkey. Since he tried to avoid any political conflict with latter, he diverted his movement to apolitical approach in his strategy to achieve his main goal that was social movement. The present study has twofold objectives. First, it focuses on Nursi's struggles in an apolitical approach. Second, it analyses his contributions to the revival of Islamic ethics and sciences through his teachings and the Nur movement. The method used in this study is qualitative, historical approach. The findings of this study disclose how Nursi directed a significant movement to the intellectual as well as spiritual life of the people in Turkey. This movement contributed tremendously to the revival of Islamic ethics and other field of sciences. After his death, his idea and thoughts has been spread all over the world helping them in their social movement.

Keywords: the New Sa'id, the Third Sa'id, the Risâle-i Nur, Medresetü'z-Zehra, apolitical approach

\section{Introduction}

Three different periods of Bediüzzaman Said Nursi had distinct characteristics depending on his political and social movements (Yusoff, 2013). During the New Sa'id period, his social movement faced a lot of oppression and mistreatment, but his innocence strengthened the movement, which now got the support of the public. Thus, unfounded negative insinuations and provocations towards Nursi had the effect of attracting the positive attention of society. His social movement resulted into a new style of works, the treatises of the Risâle-i Nur. Separate from his political movement, is his social movement, also called the text-based movement, which was organized around the treatises of the Risâle-i Nur.

\section{Personal Struggle and the Launch of a Social Movement}

Nursi's avoidance of politics became evident after his return from captivity in Russia. Nevertheless, he continued to observe politics through the newspapers and despite his unwillingness, some missions were assigned to him. A critical moment was when the country had fallen to invaders, pushing him into politics again. Until the founding of the Republic, he continued his political struggle. Since the new government practiced politics based on the European system instead of the religion-based politics, Nursi realized that they would no longer listen to his advice. He knew that his political and physical struggle would now be useless. Therefore, he isolated himself in a cave in the Erek Mountain in Van. Even when he was in Van, whenever he had communication with the people, it would cause a suspicion of government. Moreover, in 
such a critical period, it was quite normal for an âlim such as Nursi, who opposed the government's European style and who had much influence in the East, to make the government suspicious by leaving for the East. The Şeyh Said Revolt ${ }^{1}$ strengthened this possibility (Vahide, 2005, p. 180). As a result, Nursi was arrested and exiled because of suspicion. In reality, however, Nursi had strived to convince people to abandon such revolts.

Whereas, Nursi himself had followed politics until 1341(1339)2/1923, from that time on, he began to be followed by the politicians who did not give him any peace. Some ulema and şeyhs had turned them against the traditions of Islam by provoking them through revolt, negative action etc. Nursi had felt a reaction from the government against the ulema which started attacking Islamic traditions and ethics. Then the government started to make revolutions against the Islamic traditions. They stopped whoever opposed them politically or physically by arms and captured and exiled whoever opposed them ideologically. This was one of the reasons which made Nursi to shun ideological struggle as well. From then on, Nursi's spiritual and ideal dimensions became more evident day by day. However, whereas Nursi wanted to develop his spiritual personality by withdrawing himself to the cave, he was given ample opportunity to develop it in the exiles and in the prisons under the oppressions instead.

From then on, in 1923, Nursi entered a new period which he called the New Sa'id period. The previous period had become the Old Sa'id period. Whereas Nursi had tried to convey his messages beginning with the elite of the society (hawas) to the common men (awam) in the Old Sa'id period, in the New Sa'id period he addressed society by giving his messages directly to the lower sections of society. When he went to Van and stayed there between 1923 and 1925, he stayed in the Nurşin Mosque, gave lectures to his visitors, and gave speeches during the Friday prayers. In one of the summer months in 1924, he withdrew to a ruined church with a few of his students, and he spent his time in prayers, worships, and remembrances of God. When winter came, he asked his students to make a den in which he continued his prayers (Badıllı, 1998, p.648). He was always reciting the litanies, prayers and supplications in the Mecmuatü'l-Ahzab. ${ }^{3}$ At the same time, he was trying to establish a movement which would come into being in the future. Although his action of withdrawing is similar to the way of tasawwuf, it was different from the traditional Sufi order. He tried to discover a shorter way than tasawwuf (Badıllı, 1998, p.651). However, in the period of the New Sa'id which became more evident afterwards, Nursi would describe his withdrawing himself to the cave in the Erek Mountain as self-interest (Nursi, 1995, p.70).

By the dissolution of the Ottoman Empire after the First World War, the Laz, Circassian, Kurd and especially Armenians (Akgündüz, 1999, p.284) put up efforts to establish their own states. Some of the Kurdish groups visited Nursi several times requesting him to support and join their revolts. However, Nursi refused all their offers. He did not want to turn his sword against the Turks who had carried the flag of Islam for a thousand years since the reign of Abbasids. He tried to avoid their attempts to involve him in the revolts, giving them the same answers he had given to the ones who wanted to rebel in the name of Islam against Turkish authorities. However, after this rebellion called the Şeyh Said Revolt in February 1925, although Nursi was not involved, the Republic government took him from his cave on Erek Mountain, to Istanbul and then Burdur, on suspicion of possible involvement in the incidents. The revolt launched Nursi's exile and imprisonment process, although he had declined to support the revolt.

In the period of the Old Sa'id, he had addressed the ulema, the tribal chiefs, the governors, the Sultan, the Paşas, the soldiers, the newspaper reporters and the Muslim committees and societies either meeting them face to face or through the newspapers, or through the pamphlets he published. From then onwards, he started to address his own soul by writing some truths in the form of small pamphlets in Burdur addressed to the New Sa'id. His writing style changed too, from addressing the outer world to a new focus of man's self. He told the people around him in Burdur about these truths. Afraid that he had won the favor of the people, the government exiled him to Isparta, where he got more followers and visitors. Then again, he was sent to a village called Barla where the only means of transportation available was crossing the lake by boat.

Nursi launched his social movement in exile in Barla. The first person Nursi met in Barla was Muhajir Hafiz Ahmed,

\footnotetext{
${ }^{1}$ Şeyh Said Revolt that broke out on 13 th February 1925 was named with a Nakşibendî şeyh called Şeyh Said of Palu. It was considered a reactionary revolt by Republican government. The government used the revolt as a pretext for rushing through the Law for the Maintenance of Order, passed March 4, 1925, which empowered them to set up the notorious Independence Tribunals and gave them dictatorial powers to pursue their policies without opposition. The revolt launched Nursi's exile and imprisonment process in spite of his not concerning the revolt.

2 On 26 th December 1925, upon passing a law which allowed usage of Gregorian calendar, no more Ottoman Fiscal Rûmî calendar was used. Therefore, we will not use it from this time onwards either.

${ }^{3}$ Mecmuatü'l-Ahzab is a book in which most of the saints' supplications were gathered and prepared by Şeyh Ahmed Ziyaeddin Gümüshânevî.
} 
an imam of a small masjid called Yokuşbaşı Mescidi. ${ }^{4} \mathrm{He}$ accommodated Nursi in his house for a week and then he arranged for him the villagers' gathering house in which Nursi lived till the end of his first exile. In the summer, Nursi used to go to the remote areas and the tops of mountains, such as Çam Dağı which were at a distance of three or four hours by walking. He would stay there for two to three months. During his eight years stay in Barla, he won the favor of people most of whom became his students. These new students included some of officers, lawyers, and doctors, who were on duty in Eğirdir town of which Barla was a sub-village, in addition to the imams and the farmers in the village. Although he did not have any book with him, his satisfactory answers to the questions of his students caused an increasing in the numbers of students from modern mekteb. Barla village became a form of medrese. $80 \%$ of the Risâle-i Nur were written and disseminated from here to Isparta and its vicinity through the secret postal system run by the Nur Postacıları (Nur Postmen) (Şahiner, 1981, p.108). The treatises were reproduced by those who had good handwritings. Nursi had accepted the visitors who came with sincerity as his students. These students kept communication with their master Nursi, through letters and by reading and writing the treatises that were sent by Nursi. With this, Nursi laid the foundation of a new movement with the villagers in Barla.

In 1928, the new government passed new laws regulating religious matters and putting more limits on the religious people. They started to change many of the signs of Islam which Muslims were very sensitive to practice, such as changing of Arabic alphabet into Latin alphabet, making the ezan (prayer call) in Turkish instead of Arabic, replacing father's name with surname, replacing turban and gown with hat and jacket, replacing women's Islamic head cover with hats or totally removing it, etc. All these were done in the name of Atatürk inklapları (The Revolutions of Atatürk). During this time, all formerly exiled people were allowed to return to their hometown, under pardon, except Nursi. In fact Nursi himself did not want to condescend by applying to the government for the pardon. He preferred to stay in his exile in Barla. It was here that had founded his mission to serve the Qur'an, having dedicated students to help him in his mission. Thus, he apparently did not want to leave his project halfway. In 1931, when the government got the information of the activities of Nursi, they sent a teacher to the village to disturb him. The teacher was acting in cooperation with his father the Mufti of Eğirdir, qaimaqam of Eğirdir and the administrative head of Barla. Between 1931 and 1934, the oppressions on Nursi and his students increased after these officials gave negative reports to the government. Many of the people who continuously visited Nursi started to cut relationship and avoided him because he and his students called ezan in Arabic secretly. At the same time, the aforementioned teacher had opened a "Turkish Home" in which he taught about Turkish nationalism and made propaganda against Nursi for being a Kurd. Nursi sent a reminder twice to the father of the teacher, who was Mufti of Eğirdir. After 1931, Nursi's masjid was attacked twice and after the attack in 1934, it was locked up and sealed by the authorities. In the following months Nursi was not allowed to meet anybody. Soon after that he was moved from Barla to the city center of Isparta.

The later life of Nursi till 1950's was spent in the prisons and the exiles alternately. Although Nursi did not act as a negative or physical opposition, he did not practice, according to his own statement the discretionary laws that the government had brought into force. This made the government suspicious; thereby deciding to continuously keep him under surveillance. Meanwhile, Nursi had his treatises copied and disseminated. From then on, this work transformed into a rooted system which was difficult for the government to prevent. Nursi's sincere students disseminated these treatises, copying them by hand. In the summer of 1934, Nursi was sent from Barla to Isparta where he continued to write his treatises until April 1935 while still under surveillance. In the Kurban Bayramı (the Feast of the Sacrifice) the government stationed a police officer for the four days of Bayram to record the identities of all the people who visited Nursi. After that, the oppressions were increased. On 20 April, the police came and collected all the books in his house, and questioned his students. They suspected Nursi because of the large number of visitors he was receiving which made them suspect that he could impress the people and make preparations for a rebellion.

In fact this was a complot rather than a suspicion. Their purpose was to arouse people's emotions to a high pitch which would make them stage a rebellion so that they could then punish them because of the excessive movement. However, Nursi and his students realized that aim and refused to become instruments to their aim. The Interior Minister, Şükrü Kaya, came to Isparta from Ankara with an additional unit of soldiers and police. The minister acted as if there was already a rebellion, although there was no evident reason. Although they did not find anything criminal in Nursi's treatises, on $25^{\text {th }}$ April 1935, after conducting an inquiry for five to six days, they arrested Nursi and his one hundred and twenty students. On $8^{\text {th }}$ May 1935 they transferred the suspects to Eskişehir Prison. Although the order of annihilation was given, the commander, who was in charge of the transferred suspects, did not obey the order. The newspapers of the time had reported these events in an exaggerated way as if Nursi and his students had tried to overthrow the government. Three months later, the courts gave Nursi a sentence of imprisonment for twelve months and one year's surveillance in

${ }^{4}$ Yokuşbaşı Mescidi was the masjid which is now next to Nursi's current museum house in Barla. 
Kastamonu. The sentence for each one of his students was also imprisonment for six months.

In the spring of 1936, Nursi was brought to Kastamonu. After three months in police custody, he was moved into the house opposite the police station. Although the sentence had been only a year's surveillance, he stayed in Kastamonu for around seven and half years under surveillance, without any charge or court sentence. He kept communication with his students, who were in Isparta and Barla, by mail. Kastamonu became like a second Isparta having his tens of loyal students. While Nursi was in Kastamonu, on $10^{\text {th }}$ November 1938, Mustafa Kemal died, and İsmet Inönü became the president. The latter had the same revolutionary mentality as Mustafa Kemal, if not harsher.

According to Nursi, the greatest problem of the world at that point was not to gain the worldly and temporary domination through the war but it was whether each one could deserve the eternal happiness in the hereafter or not. When he was in Kastamonu, through the letters he had sent to his students who were in Isparta and Kastamonu, he had warned them not to be involved in politics. He himself had not been involved in politics for over ten years. All his treatises were spiritual and free from the influence of politics. Although the Second World War which started at the end of 1939 was related to the future of Islam, Nursi was not interested in the details of the war. With this attitude, he wanted to give a message to his students that they should stop being interested in politics.

Nursi also gave some messages that he had found out a way which was the most effective and shorter than tasawwuf (Sufi path). In 1940, Nursi was given as a gift the gown of Mawlana Khalid-i Baghdadi, who was then considered the former mujaddid (renewer) of Islam, by one of his students who had kept this trust for a long time, in Kastamonu. One of his early students and the first scribe of the New Sa'id period of Nursi, Samli Hafiz Tevfik, interpreted this trust given, as a sign of Nursi's being the renewer of the time. Although Nursi did not deny this idea which he recorded in the book, Barla Lahikası, he transferred this position to the Risâle-i Nur and the collective personality of the Nur students. While he was in Kastamonu, he used to go to the mountains to edit the drafts of the Risâle-i Nur. Whenever he went outside, a police or a watchman would follow behind him from a distance. Many wrongdoings were meted on Nursi by sending spies, pursuits, making people scared of him, torments, and scorning. Nursi had never taken any money or gift from any of his students or anybody else. He survived on his savings from the salary he had taken from Daru'lHikmeti'I-Islamiye for a while. After that he started to survive on proceeds from selling the Risâle-i Nur books. He used to sell his small belongings whenever he needed money.

Although Nursi did not meet them, he got new students through his treatises being read day by day. There were also women among them. From then on, the concept of the "Nursi's students" changed into the concept of the "Nur students". This enabled Nursi's messages to reach to the broader spheres. Although Nursi was confined to one location, his treatises instead of him started to show a great effect on people in distant cities such as Denizli, Aydın, and Afyon, where his treatises had been distributed. Atıf Egemen, the man caused the treatises to reach these cities, was arrested in Denizli following the reports of the Mufti and the General Preacher of Denizli. The reason of his arrest was that published a treatise, namely the $5^{\text {th }}$ Ray, which tells about the particular signs of the doomsday. The government directly got involved in this case. Some arrests were made in Isparta as well. In September 1943, although they searched many time the drafts of the $5^{\text {th }}$ Şu'a (5 $5^{\text {th }}$ Ray) in Nursi's and his students' houses, they could not find them. However, on 20 September 1943, Nursi was arrested again after they found 24th Flash, which was about the veil of women, in Nursi's house.

Nursi defended his individual rights and protested against the government's arbitrary laws which interpreted with his religious appearance and ideas. Moreover, he defended the rights of the individuals as being a model through his struggle against unjust applications of government especially on religious freedom. On $13^{\text {th }}$ October 1943, he was sent from Kastamonu to Isparta via Ankara. While in Ankara, Nevzat Tandoğan, the governor, had Nursi brought to his mansion. When he attempted to make Nursi wear a hat by force, Nursi cursed him. ${ }^{5}$ Nursi had never been sentenced to a serious punishment although his crimes were claimed as serious either politically or socially. There is a point to mention here that while Nursi and his students faced a death sentence, the judges could not find an article in the constitution to accuse him in response to his very strong and amazing defences (Nursi, 1998a, p. 452). ${ }^{6}$ During the trials, the judges studied the Risâle-i Nur and a knowledgeable committee examined it. The trial which started in Isparta continued in Denizli in November 1943. More than one hundred students who were arrested in Kastamonu, Ankara, Istanbul, Isparta and Antalya, were brought to Denizli with Nursi. The fact that they all came from different parts of Turkey shows how far

\footnotetext{
${ }^{5}$ One year after this incident, the governor committed suicide by shooting himself on the head.

${ }^{6}$ Nursi had requested in the Eskişehir court that his and his students' right was either death or release or a hundred and one year imprisonment or an insane asylum but not short time six months or a year imprisonments that an ordinary criminal such as an abductor of girls or a horse thief was sentenced. However, the judges had to seem doing something to get government to agree. Nursi would remind the same in the Afyon court.
} 
the Risâle-i Nur spread in 8 years despite the pressures after the Barla exile. The report of the knowledgeable committee was presented to the Denizli court. The trial which lasted over a year came to a conclusion on 15 June 1944 when the court released Nursi and his students.

By release from Denizli prison, Nursi and his students had handled the most difficult stage successfully. Nur students started to work harder and more freely. However, this Denizli court determined the future of Nur students and the service of the Risâle-i Nur. From then on, the Risâle-i Nur would not be able to be judged again by law, since even the most secret treatises had been released. The Nur movement acquired new students in Denizli as well. After the supposed release, on 31'st July 1944, Nursi was forced to settle in Emirdağ, a township in Afyon city, as a new exile by the government. The government did not want to give him any peace. They tried to buy Nursi with some favors whereby he was offered a salary and a house but he refused all. Then they oppressed him more by placing a watchman in front of his door to monitor the visitors. In spite of this, his new students in Emirdağ did not leave him alone. They went on to read, copy, and publish the Risâle-i Nur. Nursi used to go to rural areas here, followed by the watchmen. Because of prohibition of turban and the law of the hat, Nursi's wandering around made the officials suspicious. Therefore, most of the time, Nursi did not want to go outside but he never changed his dressing style.

In 1944's, Turkey's political system experienced a turning point which would influence the future of Turkey, moving it more toward democracy. The relationship between Turkey and Russia were strained. Although President Ismet Inönü expected Russia to be friendly, he had to turn his direction to America and the West. America imposed several conditions, including such as changing the dictatorial regime to democracy. If that was fulfilled, America would protect Turkey against Russia. On $26^{\text {th }}$ June 1945, Inönü had to sign the United Nations' treaty. Among the requirements of democracy, was to allow opposition parties, and respect human rights. On the $17^{\text {th }}$ January 1946, the Democrat Party was established. The government started to take some steps to cover up their previous oppressions and mistakes. The door for Hajj which had been closed till that time was opened. The Holy Qur'an teaching courses were permitted to open, and on $10^{\text {th }}$ February 1948 , the government decided to put the optional religious studies lesson in the curriculum of the primary schools. Upon the latter two permissions, Nursi asked his students to open small dershanes ${ }^{7}$ wherever they lived. The government decided too, to establish the Faculty of Islamic Theology at Istanbul University. In spite of all the efforts, the government could not keep its hold into power. In the first democratic election, the government's RPP (Republican People's Party) lost against the Democrat Party.

In the period of the so-called democratization, which started in 1945, Nursi could not take his share from that but on the contrary the pressures on him continued to increase. According to Nursi, some of the reasons of pressures were his rejection of the salary and the house, his winning favor in people's eyes by his release from Denizli court, and the Afyon governor holding a grudge against Nursi in the name of loving Mustafa Kemal. Nursi and the Nur students had experienced freedom for the first time in developments of service such as duplicating the copies of the Risâle-i Nur, going overseas, opening the dershanes and winning the support of the new generation of Nur students. In 1946, the treatises started to increase through duplicating machines owned by his students. Thousands of copies of the Risâle-i Nur were duplicated with two duplicating machine in Isparta and Inebolu. After 1946, when the embargo on performing the Hajj was lifted, through Nur students who made their pilgrimage, the Risâle-i Nur started to be spread to the Islamic world. When the government started to direct itself to the West, the service of the Risâle-i Nur was also heard in Europe and America. When Nursi moved to Emirdağ, Nur students started to be called "Nurcu", meaning the follower or supporter of the light, a name they happily appropriated. Then, the new generation students of the period of the Republic, who were educated in the Republic schools using the Latin alphabet, started to join to the old generation students who had been educated in the Ottoman mektebs using the Arabic alphabet. When the new generation students started to study the Risâle-i Nur, they also had enthusiasm to learn the Ottoman alphabet, in which the Risâle-i Nur were written, as their predecessors had been writing it with enthusiasm. However, especially in 1950's, because of the increase in this new generation students, those who could not comprehend the Ottoman alphabet increased too. Therefore Nursi, in 1956, gave permission for his students to publish the Risâle-i Nur in the new Latin alphabet.

After seven months from the founding of Democrat Party, on 21 $1^{\text {st }}$ July 1946, the government organized an undemocratic election, using a system of open vote and secret count, with the purpose of determining who voted for whom. Although they succeeded in their first experience, the Democrat Party won 66 seats in the parliament. The Democrat Party achieved a greater success in Afyon, where Nursi was an exile, than the other places. The government thought that Nursi was responsible for the Democrats' success. Then they accused Nursi for establishing the secret organization, and abetting the people to threaten public security. On $23^{\text {rd }}$ January 1948, he was arrested with 53 of his

7 Dershane is the place that Nur students accommodated and gathered to read the Risâle-i Nur. Since the development of dershanes in Turkey is discussed in details in the other chapters, I refer you to the related chapters for this topic. 
students and brought to Afyon city center. After ten months of trial, the court sentenced Nursi to 20 months imprisonment. Ahmed Feyzi, one of his senior students was sentenced to 18 months, and 18 other students to 6 months imprisonment. The 18 students were freed immediately because they had already been in prison for 11 months. Nursi and his student Ahmed Feyzi completed their prison sentences.

In 1949, the illness of unsociability reoccurred in Nursi as it had done in 1907 and 1922 . These periods of unsociability, especially the ones in 1922 and 1949, marked major transitions in his spiritual revolutions. Nursi's scholarly debates until 1907, afterwards, encouraged him for political debates in Istanbul. However, after 1922, his scholarly and political debates acquired a spiritual aspect. Integration of his scholarly, political and spiritual debates proved itself in his defenses in courts. The spiritual dimension of his defenses occurred by reminding people of the reality of the world, death, and hereafter. He answered the needlessness of political suspicions on him by touching on the political matters. $\mathrm{He}$ also gave scholarly answers to the ignorant questions of the public prosecutor. With his spiritual situation and in his Third Sa'id color, which integrated harmony the Old Sa'id and the New Sa'id, Nursi gave the guiding and leading advices to the new government, which was in favor of Islam, in the wide sphere while he educated his students in the small sphere. He did this because he wanted the service of the Risâle-i Nur to be spread quickly among the broader spheres.

Turkey was experiencing significant transitions in the 1950s. The new political circumstances made the publication of the Risâle-i Nur possible, and the Nur students became a more organized and coordinated movement (Voll, 1998, pp. 734-747). After 1950, the Risâle-i Nur was now copied using duplicating machines. However, the Democrat Party's coming to power did not solve all the problems. Because of his new published work, Gençlik Rehberi, a charge was brought again against Nursi and his young university student in Istanbul because of the printed booklet while the Afyon court continued. On $5^{\text {th }}$ March 1952, the court released Nursi and his student. Upon his release, Nursi received congratulation messages from Pakistan, Egypt, Iraq, and Jerusalem. After his release from Afyon prison, on $2^{\text {nd }}$ December 1949, he was brought to Emirdağ again.

Although the Afyon court files had been cancelled upon a general pardon declared by the Democrat government on $14^{\text {th }}$ July 1950, the books of the Risâle-i Nur were seized, charges were field, and the trials continued until 1956. At last in 1956, the Afyon court reached the final decision and released the Risâle-i Nur after being scrutinized and given affirmative report by the committee of experts and the Directorate of Religious Affairs. From then on, the Risâle-i Nur would be able to be published freely and read by everybody. This judicial decision vindicated the Risâle-i Nur once and for all. Nursi had supported the Democrat Party because they had brought back some of the Islamic traditions into practice. To protect the party, he sent them some warning letters as reminders against the activities of the irreligious ones. He voted openly for the Democrat Party in the 1957 elections, although voting was through a secret ballot. Although Nursi and his students supported the Democrat Party, were aware of the harm of politics for their service and tried to avoid getting involved. However, some of the Nur students stood as candidates in election, not in the name of the Nur students but in their own individual capacity.

Nursi had realised that there were some secret committees behind the officials and government. According to Nursi, these committees encouraged the government to attack Nursi and his students by frightening and threatening them. He claimed that behind these committees were the masons and communists. The masons were organizationally active and effective in Turkey beginning with the second half of the 19th century (Koloğlu, 2001, p.214). They had been developing new tactics and strategies against Muslims while the governments changed power. Their strategy after 1930 was to label Muslims as reactionaries, a term used after the declaration of freedom in 1908. Using these labels, they would disturb Nursi and his students saying that they were against regime or dangerous to the regime. According to them, Nursi was the leader of a Sufi order and the founder of an association. The secular newspapers wrote unfounded reports against Nursi and the Democrat Party. Wherever Nursi travelled, they reported it as a significant event. They tried to show that Nursi and the Democrat Party government had a close relationship (Ecevit, 1960). The Democrat government did not want to be directly related with the Nur movement, just as the Nur students did not want to be linked to the democratic government.

Nursi was able to travel on his own free will for the first time in 27 years. He selected Isparta as his residence. While he was in Isparta, Nursi visited some places such as Barla, Eskişehir, Emirdağ; in which he had been kept in exile and as a prisoner. Nursi continued to guide the government through letters until 1956. He warned them of some wrongdoings on him which were then starting afresh. But the effective superiority of the Democrat deputies who were close to RPP put pressure on the government to pursue Nursi. The Democrat government, which had weakened by then and anxious of losing power, got suspicions of even small matters. Thus, although Nursi had openly supported the Democrat Party government in the 1957 election, Nursi's freedom of movement came to an end. He could only travel between Emirdağ and Isparta, and sometimes Afyon and Eskişehir. They continued to pursue him until the end of his life.

Although Nursi was forbidden to travel, three months before his death, he increased the frequency of his travels 
and, feeling that his time had come, he started his farewell travel to visit his students and dershanes in Ankara, Emirdağ, Konya, and Istanbul. His visits were greeted with sensational headlines in the newspapers as ever. These exaggerated news attracted the official's attention on Nursi. He returned to Emirdağ since it was his place of obligatory residence. In Emirdağ, he became seriously ill and suddenly decided to go to Urfa. Two days before his death, he secretly went to Urfa where he wished to die. He was over eighty then. A crowd of people of Urfa gathered around the hotel in which Nursi stayed, to visit him. When the government heard of that, they asked Nursi to leave Urfa and travel back to Isparta. Nursi was so sick that he was not able to move at all. He had come to Urfa to die. He asked his students to defend himself. A quarrel ensued between Nursi's students and the police. ${ }^{8}$ As the quarrel went on, at three o'clock on Wednesday morning, 23rd March 1960, Nursi departed this life peacefully.

Ten years before his death, Nursi had sent one of his students Abdullah Yeğin to Urfa, promising him that he would come to Urfa soon. Abdullah Yeğin had been waiting his master for ten years. So Nursi kept his promise and they met only for two days when Nursi came to die in Urfa. Thousands of people from all around Turkey attended his burial. Nursi was buried in the tomb in the Halîlurrahman Dergâh, where the Prophet Abraham (PUH) lies but it was to be only a temporary resting place for him. Nursi's biography does not end with his death. He had some more adventures after his death. On the $12^{\text {th }}$ July 1960 , the Military Junta ordered the removal of Nursi's remains to an unknown spot at night. ${ }^{9}$ The soldiers exhumed his body and took his body to an unknown place, under the pretext of being a crowd of followers of Nursi. Later on, his unmarked grave was found by his students in Isparta. It is so interesting that Nursi had predicted that his grave would be demolished (Nursi, 1998b, p.727), and he had requested in his will that upon his death his grave be unknown to the public except his close students (Nursi, 1993, p.179). So the army both carried out Nursi's predict and fulfilled his will, albeit unintentionally.

\section{Concluding}

Nursi evaluated the calamities and misfortunes which had befallen Islam in the view of Divine Destiny but he defended the reformation of Islam on its basic matters under the light of Qur'an. According to him, the enemies' attacks were aimed at the roots and the foundations of Islam, such as the existence of God and related belief matters, through materialism and communism. By succeeding of his endeavours, he claimed that the Risâle-i Nur had ruined the essence of disbelief and took root strongly in the Turkish society and indirectly in the world. Thus, the next stage was the establishments which would grow from these roots. One of these basic establishments called dershane. To conclude, the main contribution of Nursi was to demonstrate his thoughts on Islamization of knowledge which was so significant at the time when the Islamic world was on the move learning towards modernization and westernization. His ability to merge between revealed knowledge and academic knowledge giving a totally new perspective on sciences from two different angles.

\section{References}

Akgündüz, A. 1999. Bilinmeyen Osmanlı. Istanbul: OSAV.

Badıll, A. 1998. Bediüzzaman Said Nursi mufassal tarihçe-i hayatı. Vol. 1, 2 \& 3. Istanbul: Calı̧ Ofset.

Ecevit, B. Nurcular ve İktidar, Akşam Gazetesi, 12 January, 1960.

Koloğlu, O. 2001. Abdulhamit ve masonlar. Istanbul: Eylül Yayınları.

Nursi, B.S. 1993. Emirdağ Lahikası II (The Letters of Emirdağ). Istanbul: Sözler Yayınevi Publication.

Nursi, B.S. 1995. The flashes collection. Istanbul: Sözler Neşriyat A.S.

Nursi, B.S. 1998a. The rays collection. Istanbul: Sözler Neşriyat.

Nursi, B.S. 1998b. The words. Istanbul: Sözler Neşriyat A.S.

Şahiner, Necmeddin. 1981. Son şahitler Bediüzzaman Said Nursî'yi anlatıyor. Vol. 2. Istanbul: Nesil.

\footnotetext{
${ }^{8}$ Especially a heated quarrel happened between Mehmed Hatiboğlu, the president of provincial assembly of the Democrat Party, and the chief of police in Urfa. The police insisted that there was a final order that came directly from the interior ministry in Ankara. Mehmed Hatiboğlu bravely defended Nursi that he was their honored guest and that there was no question of his being treated in this way. However, the police had to follow order of the Interior Ministry. The people who came to visit Nursi declared they would not let Nursi go. The Democrat Chairman brought a government doctor, who examined Nursi. His temperature rose up to $40^{\circ} \mathrm{C}$. The doctor pronounced him unfit to travel.

${ }^{9}$ That night the town had been taken over by the army. There was a strict curfew, and no one was allowed on the streets. Tanks and armored vehicles had been positioned at all key points in the town. The Dergâh was surrounded by a tight cordon of soldiers. Acting on the orders they had received, soldiers entered the twin-domed building containing Nursi's tomb, not by the door, but by breaking the iron grill on the windows. They then began to smash the marble slabs of the tomb with hammers.
} 
Vahide, Ş. 2005. Islam in modern Turkey; an intellectual biography of Bediüzzaman Said Nursi. Ed. by Ibrahim M. Abu-Rabi. Albany: State University of New York Press.

Voll, J.O. 1998. Renewal and reformation in the mid-twentieth century: Bediuzaman Said Nursi and religion in the 1950's. In Sukran Vahide (ed.). A contemporary approach to understanding the Qur'an, the example of The Risale-i Nur, International Symposium on Bediüzzaman Said Nursi, pp. 734-747. Istanbul: Sözler Publications.

Yusoff, K. 2013. Transition in Turkey: An Overview of Bediüzzaman Said Nursi, His Life and Works for Medresetü'z-Zehra. International Journal of West Asian Studies. Vol. 5 No. 2. Pp: 67-77. DOI: 10.5895/ijwas.2013.11 